\title{
Effects of soil management practices and irrigation on plant water relations and productivity of chestnut stands under Mediterranean conditions
}

\author{
A. Martins • F. Raimundo • O. Borges • \\ I. Linhares $\cdot$ V. Sousa $\cdot$ J. P. Coutinho $\cdot$ \\ J. Gomes-Laranjo • M. Madeira
}

Received: 22 January 2009 / Accepted: 12 May 2009/Published online: 2 June 2009

(C) Springer Science + Business Media B.V. 2009

\begin{abstract}
The effects of different soil management practices and irrigation on plant water relations, physiological response and productivity of chestnut stands in Northeastern Portugal were assessed during four growing seasons (2003 to 2006). Treatments were: conventional soil tillage up to $15-20 \mathrm{~cm}$ depth with a tine cultivator thrice a year (CT); no tillage with spontaneous herbaceous vegetation $(\mathrm{NV})$; no
\end{abstract}

Responsible Editor: Tibor Kalapos.

A. Martins $(\varangle) \cdot$ F. Raimundo $\cdot$ I. Linhares $\cdot$ V. Sousa Universidade de Trás-os-Montes e Alto Douro (UTAD), Apart. 1013,

Vila Real 5001-801, Portugal

e-mail: amartins@utad.pt

\section{O. Borges}

Direcção Regional de Agricultura do Norte (DRAPN), Delegação do Nordeste Transmontano,

Av. General Humberto Delgado,

Bragança 5301-903, Portugal

J. P. Coutinho $\cdot$ J. Gomes-Laranjo

Centro de Estudos da Terra, do Ambiente e da Vida,

UTAD,

Apart. 1013,

Vila Real 5001-801, Portugal

M. Madeira

Instituto Superior de Agronomia,

Universidade Técnica de Lisboa,

Tapada da Ajuda,

Lisboa 1349-017, Portugal tillage with rainfed seeded pasture (NP); and no tillage with irrigated seeded pasture (NIP). Results suggest that soil water availability was the most critical parameter for chestnut productivity over the study period. In all treatments, high predawn leaf water potentials $(-0.40$ to $-0.55 \mathrm{MPa})$ were observed during the dry seasons of 2003, 2004 and 2006, showing no critical conditions for plant productivity, which is ascribed to water availability in deep soil layers. In contrast, in 2005, an extremely dry year, water potentials decreased and varied from -1.46 to $1.72 \mathrm{MPa}$ in late summer, showing unfavourable conditions for nut production. Maintenance of spontaneous herbaceous vegetation without irrigation enhanced productivity of chestnut stands as compared with the conventional tillage system and the no tillage system with seeded pasture. Productivity in the soil watering system (NIP treatment) was not significantly different from that observed in the NV treatment. Therefore, studies on the irrigation strategy should be developed, in order to increase its efficiency especially in stands with young trees.

Keywords Agroforestry systems · Castanea sativa . Crop tree irrigation - Soil and plant water relations . Soil tillage $\cdot$ Soil water depletion
Abbreviations
$\mathrm{CV}$ Conventional tillage
DHB Diameter at Breast Height 
h tree height

NIP No tillage with irrigated seeded pasture

NP No tillage with rainfed seeded pasture

NV No tillage with herbaceous spontaneous vegetation cover

P Photosynthetic rate

$\Psi_{\text {wpd }}$ Predawn leaf water potential

\section{Introduction}

Chestnut plantations for fruit production are an important agroecosystem in Europe, where they occupy about 117,000 ha, especially in Mediterranean area, with 110,000 ha, representing 94\% of total Europe and $33 \%$ of the total world chestnut area (FAO 2004). Nowadays, in Northern Portugal, these systems occupy an area about 25,000 ha, being responsible for about $84 \%$ of the total national nut production (INE 2005) and are an essential source of income for rural areas and an important feature of the landscape. As one of the most profitable productive systems of the region, there is a great concern about the intensive management practices which are commonly used in those plantations, such as soil tillage, fertilization, pruning and irrigation (Portela et al. 1999; Raimundo 2003; Martins et al. 2005). Some of these practices have been considered a threat for soil quality and system sustainability (Abreu et al. 1993; Martins and Abreu, 1997; Portela et al. 1999).

Soil tillage is commonly carried out three or four times a year with a tine cultivator to incorporate organic residues into the soil, destruct soil surface crust, control weeds and save soil water (Portela et al. 1999; Raimundo 2003). However, no significant advantages of conventional tillage have been observed regarding water saving and nut production, when compared with less intensive practices, such as no tillage with maintenance of spontaneous herbaceous vegetation (Raimundo 2003). Furthermore, several negative impacts have been reported for the conventional tillage system: (i) decrease of soil organic matter content and biodiversity; (ii) increasing risks of soil compaction, soil erosion and nutrient losses; (iii) damage to tree roots, which enhance the occurrence of ink disease induced by Phytophthora cinnamomi
(Hogue and Neilsen 1987; Glenn and Welker 1989; Lipecki and Berbeć 1997; Martins et al. 1999; Portela et al. 1999; Marcelino et al. 2000). Therefore, it is crucial to identify the proper soil tillage systems in the chestnut plantations to improve their productivity and sustainability, and to ameliorate soil quality.

Water deficit is one of the main constrains to tree growth and biomass production in Mediterranean conditions given the scarce rainfall during the growing season, therefore creating a large water deficit from May to September (INMG 1991; SNIRH 2005). In a strongly seasonal dry climate, the long-term sustainability of these ecosystems may be further threatened by the regional effects of global warming, which are predicted to result in increases in the length, severity and frequency of summer droughts (Miranda et al. 2002). In these circumstances, water availability is a main concern of producers, and irrigation has been experienced by some of them, although in an empirical way and without evaluation of its effect on soil plant relationships and productivity. However, water is a scarce resource and competition for its use between different activities, such as agriculture, industry and municipalities is dramatically increasing (Fereres and Evans 2006; Pereira et al. 2002a and b). Moreover, impacts of irrigation on the environmental quality are also of great concern (Stigter et al. 2006), and improving water use efficiency should be encouraged to optimize the use of that limited resource.

Replacement of conventional tillage by no tillage system in cereal crops has been reported to increase soil water storage (Lyon et al. 1998). Also, competition for water in intercrops has been reported to be negligible or absent (Morris and Garrity 1993). In this context, less intensive soil management (with spontaneous herbaceous vegetation or seeded pasture) and water supply might positively affect the functioning and productivity of chestnut plantations. Therefore, an experimental trial was established in a chestnut plantation, in 2001, (i) to evaluate whether soil management practices, including irrigation, affect tree water relations, tree physiologic response and nut productivity, and (ii) to develop base guidelines for improvement and sustainable productivity of chestnut plantations growing under Mediterranean conditions. 


\section{Materials and methods}

Site description

The study was carried out by an experimental trial established on a private estate, in October 2001, in Northeast Portugal, municipality of Macedo de Cavaleiros $\left(41^{\circ} 35^{\prime} \mathrm{N}\right.$ and $6^{\circ} 57^{\prime} \mathrm{W}, 700 \mathrm{~m}$ altitude). The climate is of Mediterranean type with cool and wet winters and warm dry summers. Considering the available climatic data for the meteorological station at Bragança (30 km far from the experimental site), for the period 1970-2000, the mean annual rainfall was $818 \mathrm{~mm}$, mainly concentrated from October to May (85\%) (Fig. 1). The monthly distribution of rainfall and reference evapotranspiration, according to Hargreaves (1975), is shown in Fig. 1, which illustrates the climatic water deficit in the experimental area during the summer period. The mean annual temperature was $11.9^{\circ} \mathrm{C}$ (INMG 1991), and monthly mean air temperature ranged from $3.4^{\circ} \mathrm{C}$ in winter (December) to $22.4^{\circ} \mathrm{C}$ in summer (August).

The landscape of the study area is gently undulating with slopes varying from 0 to $4 \%$. The soils in the experimental area are developed on schists (Siluric formation), and show an Ap horizon down to $20 \mathrm{~cm}$ depth, and a C horizon down to 50-90 cm, being mostly classified as Dystric Regosols (FAO 2006). As the underlying rock (schists) is fracturated (mostly vertically) and not compact, which facilitate rooting in deep layers, the rooting depth is commonly deeper than the $\mathrm{C}$ horizon. Texture of both horizons is mostly sandy loam to loam. Chemical characteristics strongly differ between the $\mathrm{Ah}$ and $\mathrm{C}$ horizons (Table 1). In the former,
$\mathrm{pH}$ values $\left(\mathrm{H}_{2} \mathrm{O}\right)$ range from 4.5 to 5.4 and contents of organic $\mathrm{C}$ and exchangeable base cations are low. In contrast, extractable $\mathrm{P}$ and $\mathrm{K}$ contents are high and reach 185 and $205 \mathrm{mg} \mathrm{kg}^{-1}$, respectively; the high $\mathrm{P}$ content is related to heavy fertilizer application, while that of $\mathrm{K}$ is associated to the nature of soil parent material. The subsurface horizon ( $\mathrm{C}$ horizon) shows extremely low contents of organic $\mathrm{C}$ and nutrients, and is much more acidic than the Ah horizon.

\section{Experimental layout}

In October 2001, an experimental system was installed in a 40 year old stand of Castanea sativa Miller (Longal cultivar) at a spacing $12 \times 12 \mathrm{~m}$. The average trunk diameter at breast height (DBH), crown projected area and height (h) of trees were $39.8 \mathrm{~cm}, 86.0 \mathrm{~m}^{2}$ and $9.9 \mathrm{~m}$, respectively. The experimental design consisted of four treatments: (a) Conventional soil tillage (reference or control) down to 15-20 cm depth with a tine cultivator thrice a year, that is, after fruit harvesting and litter fall to incorporate organic residues into the soil, in late winter to incorporate fertilizers, and in late spring for soil surface crust destruction and control weeds (CT); (b) No tillage with spontaneous herbaceous vegetation $(\mathrm{NV})$; (c) No tillage with rainfed seeded pasture (25 kg seed /ha) (NP); and (d) no tillage with irrigated seeded pasture (NIP). Each treatment (replicated three times) was installed in plots randomly distributed in the experimental area, each one with $600 \mathrm{~m}^{2}$ and six trees. At the beginning of the experiment the following fertilizers were applied: $5,000 \mathrm{~kg}$ of calcareous compost $\left(80 \% \mathrm{CaCO}_{3} ; 19 \%\right.$ $\left.\mathrm{MgCO}_{3}\right), 1,000 \mathrm{~kg}$ of superphosphate $(18 \%), 500 \mathrm{~kg}$
Fig. 1 Monthly average values for rainfall $(\mathrm{R})$ and reference evapotranspiration (ET0) in the region of the experimental area, for the period 1970-2000. Gray colour area represents the climatic water deficit period

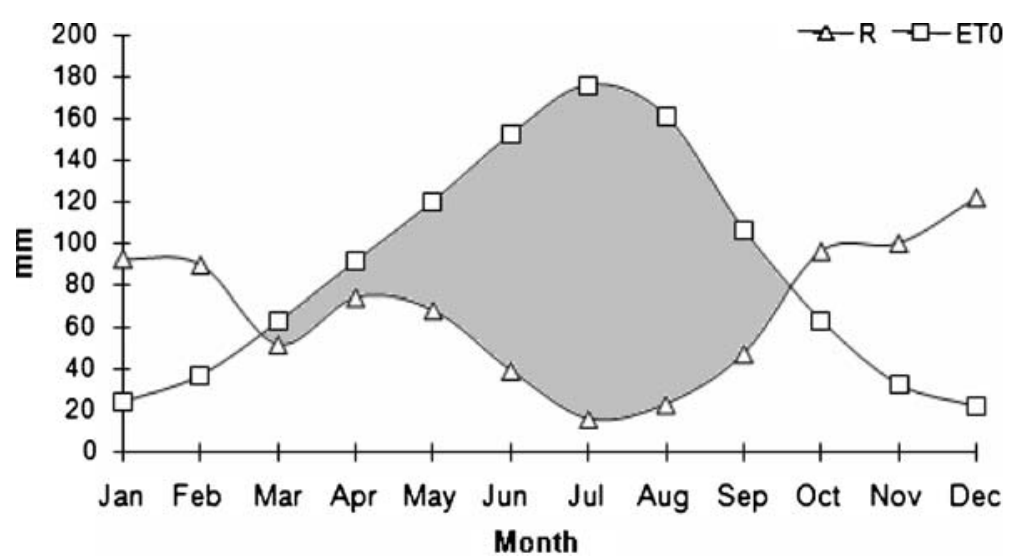


Table 1 Values of $\mathrm{pH}$, and contents of organic C, extractable $\mathrm{P}$ and $\mathrm{K}$, base cations and exchangeable acidity (EA) for surface and subsurface horizons of soils of the experimental area. Values correspond to means of six pedons

\begin{tabular}{|c|c|c|c|c|c|c|c|c|c|c|}
\hline \multirow{2}{*}{$\begin{array}{l}\text { Depth } \\
\mathrm{cm}\end{array}$} & \multirow{2}{*}{$\begin{array}{l}\text { Org C } \\
\mathrm{g} \mathrm{kg}^{-1}\end{array}$} & \multirow{2}{*}{$\begin{array}{l}\mathbf{P} \\
\mathrm{mg} \mathrm{kg}^{-1}\end{array}$} & \multirow[t]{2}{*}{$\mathbf{K}$} & \multicolumn{2}{|l|}{$\mathbf{p H}$} & \multirow[t]{2}{*}{$\mathrm{Ca}$} & \multirow{2}{*}{\multicolumn{2}{|c|}{$\begin{array}{l}\text { Mg } \\
\mathrm{cmol}_{\mathrm{c}}{ }^{+} \mathrm{kg}^{-1}\end{array}$}} & \multirow[t]{2}{*}{$\mathbf{N a}$} & \multirow[t]{2}{*}{ EA } \\
\hline & & & & $\mathrm{H}_{2} \mathrm{O}$ & $\mathrm{KCl}$ & & & & & \\
\hline $0-20$ & 15.3 & 185 & 205 & 5.1 & 3.6 & 2.19 & 0.54 & 0.50 & 0.04 & 1.05 \\
\hline $20-50$ & 4.1 & 4 & 99 & 4.6 & 3.3 & 0.95 & 0.36 & 0.22 & 0.03 & 3.17 \\
\hline
\end{tabular}

of $\mathrm{KCl}$, and $10,000 \mathrm{~kg}$ of organic fertilizer $(50 \%$ of moisture, $69 \%$ organic matter; $1,5 \% \mathrm{~N} ; 1,5 \% \mathrm{P}_{2} \mathrm{O}_{5}$, $\left.0,25 \% \mathrm{~K}_{2} \mathrm{O} ; 1,7 \% \mathrm{CaO} ; 0,3 \% \mathrm{MgO}\right)$.

Irrigation (two sprinklers) was applied to three trees per plot, that is, nine irrigated trees were considered in the NIP treatment. The amount of irrigation water was $217,78,220$ and $70 \mathrm{~mm}$, which was supplied by $14,7,19$ and 7 water applications in 2003, 2004, 2005 and 2006, respectively. In 2003, 2004 and 2005, the dates and volumes of irrigation were adopted according to the schedule of irrigation followed by the land owner, taking into account the rainfall and temperature during the summer period. For 2006, the irrigation was made only from 14 August to 15 September, taking as reference the minimum value of $-0.6 \mathrm{MPa}$ for predawn leaf water potential, and balancing the reference evapotranspiration to the experimental area conditions, calculated according to Hargreaves (1975).

In NP and NIP treatment plots, the pasture (a mixture of Dactilis glomerata L., Lolium multiflorum Lam., Trifolium subterraneum L., T. repens L., and T. pratense L.) was seeded in October 2001, using $25 \mathrm{~kg} \mathrm{ha}^{-1}$ of the mixture, and covered by chisel, after spreading the seeds. In the NV treatment spontaneous herbaceous vegetation was mainly composed of Chamaemelum mixtum (L.) All., Ornithopus compressus L., Rumex acetosella L. subp. angiocarpus (Murb.) Murb. and Vulpia bromoides (L.) S.F. Gray. The vegetation in NV, NP and NIP treatments covered about $100 \%$ of the soil surface and was controlled by grazing and one cutting in late spring. Fertilization was the same for all treatments, as previously reported.

Measurements and samplings

Rainfall and air temperature were daily recorded in the experimental area during the study period, using an automatic weather station (DELTA-T Devices, Logger type DL2, with Software Ls2Win 1.0). The reference evapotranspiration (ET0) was estimated using the Hargreaves method (Hargreaves 1975), taking into account the available climatic data.

Volumetric soil water content $(\theta)$ was measured with a TDR device (Time Domain ReflectometryTrase System, Soil Moisture Equipment), at $0-15 \mathrm{~cm}$, 0-30 cm, $45 \mathrm{~cm}$ and $75 \mathrm{~cm}$ soil depth during the dry season. Measurements at the $0-15$ and $0-30 \mathrm{~cm}$ soil layers were made with $15 \mathrm{~cm}$ and $30 \mathrm{~cm}$ length wave guides (Ref. 6008 L15 and 6008 L30 respectively), placed vertically, each one with 12 replications per treatment, that is, four in each treatment plot, while for those at $45 \mathrm{~cm}$ and $75 \mathrm{~cm}$ depth, buriable wave guides (model 6005 L2, Soil Moisture Equipment) were horizontally installed, with six replications per treatment (two per treatment plot). Devices were placed at middle distance between the limit of tree crown projection and the tree trunk. The measurements were carried out during the study period, generally once a week.

To assess the pattern of plant water uptake from soil profile, soil moisture content at $0-30$ and $75 \mathrm{~cm}$ depth was compared with soil water content measured at $-1.5 \mathrm{MPa}$ pressure, that is, the threshold corresponding approximately to the wilting point (Brady and Weil 1999; Hillel 2004), on undisturbed soil samples of the same layers. This value has been used as a reference generally accepted for the wilting point of the majority of plants (Kramer 1969; FAO 1979; Marshall and Holmes 1988; White 2006). Sixteen undisturbed soil samples were taken at both $15 \mathrm{~cm}$ and $75 \mathrm{~cm}$ depths and processed at $-0.033 \mathrm{MPa}$ and $-1.5 \mathrm{MPa}$ pressure chamber apparatus.

Tree water status was assessed by measuring predawn $\left(\psi_{\text {wpd }}\right)$ and midday $\left(\psi_{\text {wmd }}\right)$ leaf water potentials with a Schölander-type pressure chamber (PMS 1000, PMS Instrument ${ }^{\mathbb{R}}$ Corvallis, Oregon, 
USA). Gas exchanges were estimated with an Infrared Gas Analyzer (IRGA, mod. LCA-2, Analytical Development $\mathrm{Co}^{\circledR}$, Hoddesdon, UK). For both studies, leaves were selected up to $3 \mathrm{~m}$ high from the external south facing side of the tree crowns. Twelve readings (four per tree) were made in each treatment plot at 7:00, 9:00, 11:00 and 13:00 from June to September in 2003, 2004 and 2006, and from August to September in 2005.

The amount of leaves and burs was evaluated through litter traps of $1 \mathrm{~m}^{2}$ which were located under the canopy (two per tree) of three trees per treatment plot, that is, 18 litter traps per treatment. Nut production was estimated through the amount of fruits collected in three trees per plot (nine trees per treatment).

\section{Statistical analysis}

For soil moisture contents and physiological parameters, a one-way ANOVA and a post hoc test, by year and date, were performed to analyse treatments effect. For litterfall and nut production, the analysis of variance ANOVA was followed, considering as sources of variation the year and treatments, their interaction and the error effects (trees by treatment and year), with the correspondent post hoc test for year and treatment effects. In both cases the JMP (SAS, Institute Inc.) software and for the post hoc the Tukey HSD multiple comparison test (for a significance level $\mathrm{p}<0.05$ ) were used.

\section{Results}

Climatic data

Taking into account the importance of water deficit and the framing of the present study, the rainfall data recorded in the experimental area were organized according to the growth years (October to September), and are reported in Table 2, considering separately the CT, NV and NP as non-irrigated treatments and the irrigated treatment, NIP.

Rainfall showed a wide variability during the study period. The total rainfall from October to May reached $1,154.1 \mathrm{~mm}, 644.9 \mathrm{~mm}$ and $631.5 \mathrm{~mm}$ for 2002/2003, 2003/2004 and 2005/2006, respectively. These values were higher than the reference evapotranspiration in all the treatments for the same period. In 2004/2005 rainfall for the same period was only $437.1 \mathrm{~mm}$ for both non-irrigated and irrigated treatments, being close to the reference evapotranspiration value $(431.7 \mathrm{~mm})$.

During the summer period (June-September), rainfall ranged from $133.7 \mathrm{~mm}$ in 2003 to $47.3 \mathrm{~mm}$ in 2006, while water deficit in the same period varied from $470.5 \mathrm{~mm}$ in 2003 to $582.5 \mathrm{~mm}$ in 2005 , for the non-irrigated treatments, and from $253.5 \mathrm{~mm}$ in 2003 and $444.9 \mathrm{~mm}$ in 2006 for the irrigated treatment (Table 2).

In contrast to rainfall, monthly temperatures did not show strong differences among study years, and were close to the average for 1970-2000.
Table 2 Rainfall (R, mm), reference evapotranspiration (ETO, mm) and water deficit (R-ETO, mm) in the periods of October-May and June-September (the summer period) in non-irrigated (CT, NV, NP) and irrigated (NIP) treatments

\begin{tabular}{|c|c|c|c|c|}
\hline \multirow[t]{2}{*}{ Year } & \multirow[t]{2}{*}{ Climatic Param } & \multicolumn{2}{|c|}{ June - September } & \multirow{2}{*}{$\begin{array}{l}\text { October-May } \\
\text { All Treatments }\end{array}$} \\
\hline & & CT, NV, NP & NIP & \\
\hline \multirow[t]{3}{*}{$2002-03$} & $\mathbf{R}$ & 133.7 & 350.7 & $1,154.1$ \\
\hline & ET0 & 604.2 & 604.2 & 443.8 \\
\hline & R-ET0 & -470.5 & -253.5 & 710.3 \\
\hline \multirow[t]{3}{*}{ 2003-04 } & $\mathbf{R}$ & 93.5 & 171.5 & 644.9 \\
\hline & ET0 & 588.3 & 588.3 & 418.6 \\
\hline & R-ETO & -494.8 & -416.8 & 226.3 \\
\hline \multirow[t]{3}{*}{ 2004-05 } & $\mathbf{R}$ & 47.3 & 244.9 & 437.2 \\
\hline & ET0 & 629.8 & 629,8 & 431.7 \\
\hline & R-ETO & -582.5 & -384.9 & 5.4 \\
\hline \multirow[t]{3}{*}{ 2005-06 } & $\mathbf{R}$ & 93.5 & 163.5 & 631.5 \\
\hline & ET0 & 608.4 & 608.4 & 488.7 \\
\hline & R-ETO & -514.9 & -444.9 & 142.8 \\
\hline
\end{tabular}


a

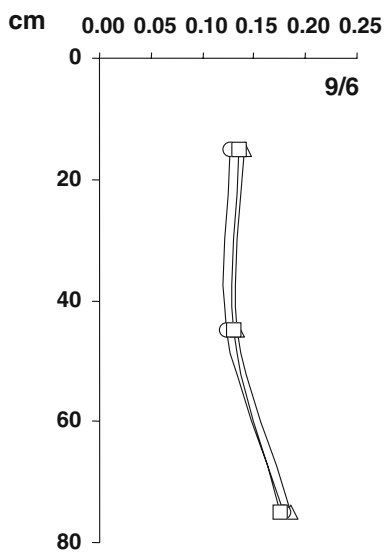

cm

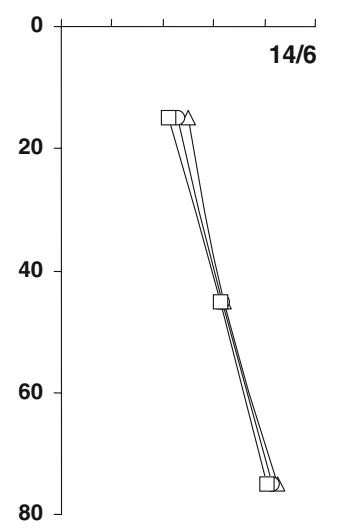

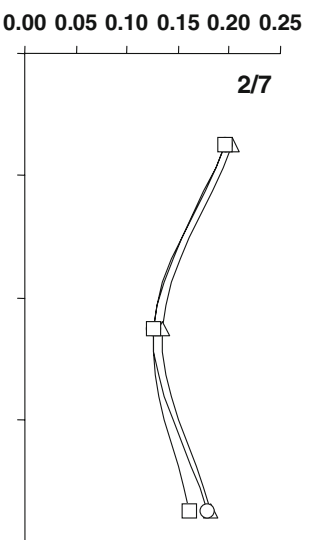

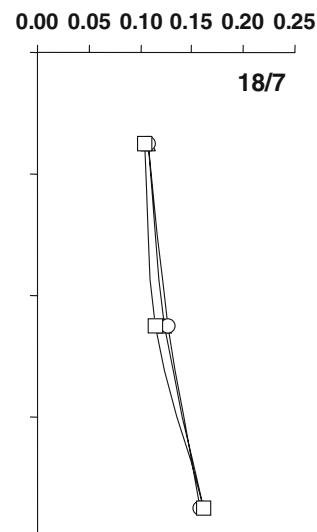

b
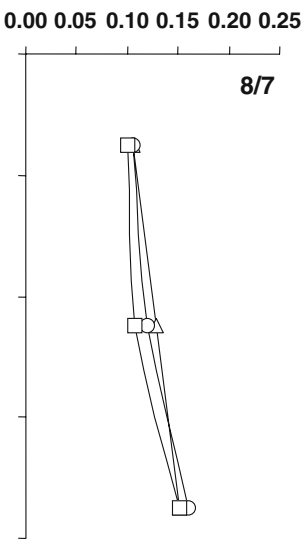

0.000 .050 .100 .150 .200 .25

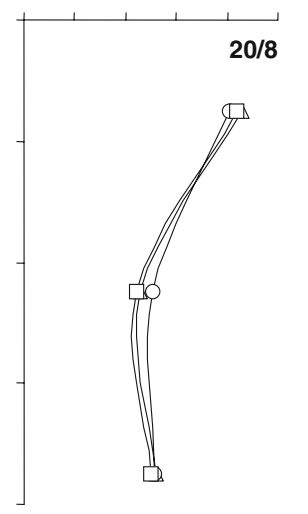

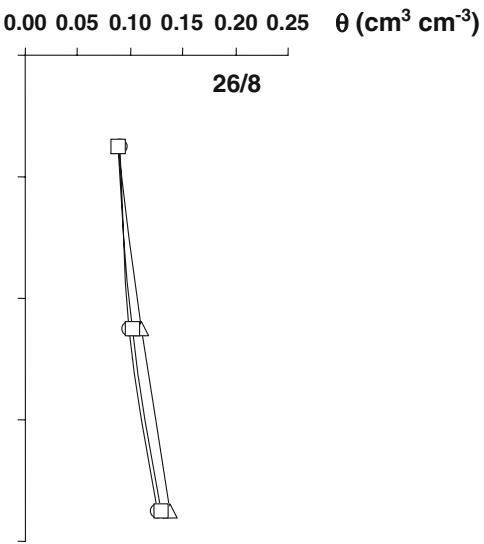

$0.000 .050 .100 .150 .200 .25 \quad \theta\left(\mathrm{cm}^{3} \mathrm{~cm}^{-3}\right)$

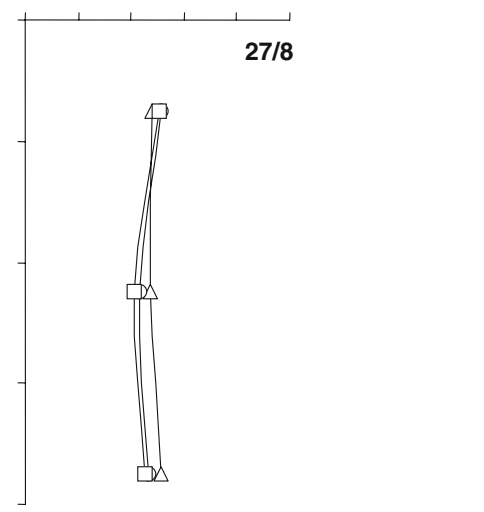
$\neg-\mathrm{CT} \leadsto \mathrm{NV}-\square-\mathrm{NP}$

Fig. 2 Soil moisture $(\theta)$ content $\left(\mathrm{cm}^{3} \mathrm{~cm}^{-3}\right)$ up to $75 \mathrm{~cm}$ soil depth, in CT, NV and NP treatment plots, in summer 2003 (A) and 2004 (B). Standard errors are too small to be shown. No significant differences were detected at the same date between treatments

Soil moisture regime

Values of soil moisture measured (in 2003 and 2004) to assess the effect of the conventional tillage and the no tillage systems on soil moisture content, with the maintenance of vegetation cover, are shown in Fig. 2. The results showed a general trend of no positive effect of conventional tillage (CT) on soil moisture content. In fact, soil moisture in this treatment was not significantly different $(\mathrm{p}>0.05)$ from the others. Also, moisture contents in the NP treatment (with rainfed seeded pasture) were similar to those measured in the treatment with spontaneous herbaceous vegetation cover (NV treatment).

The variation of available water for plants in the soil profile of CT plots $(30 \mathrm{~cm}$ and $75 \mathrm{~cm}$ soil depth) along the drought period, in 2003, 2004, 2005 and 2006 , as well as the values measured at $-1.5 \mathrm{MPa}$ $\left(0.10 \mathrm{~cm}^{3} \mathrm{~cm}^{-3}\right.$ at $30 \mathrm{~cm}$ and $0.12 \mathrm{~cm}^{3} \mathrm{~cm}^{-3}$ at $\left.75 \mathrm{~cm}\right)$ and at $-0.033 \mathrm{MPa}\left(0.26 \mathrm{~cm}^{3} \mathrm{~cm}^{-3}\right.$ at $30 \mathrm{~cm}$ and $0.27 \mathrm{~cm}^{3} \mathrm{~cm}^{-3}$ at $75 \mathrm{~cm}$ ), corresponding respectively to the wilting point and to the field capacity, are shown in Fig. 3. Soil moisture content at the $30 \mathrm{~cm}$ soil depth (which was at summer beginning lower than the field capacity) tended to strongly decrease during the summer period, reaching contents lower than that measured at $-1.5 \mathrm{MPa}$. However, a wide temporal variability was observed, as moisture contents much higher than those measured at $-1.5 \mathrm{MPa}$ were determined in August (in 2004 and 2006) in relation to rainfall events during the summer. Soil moisture contents measured during the dry season of 


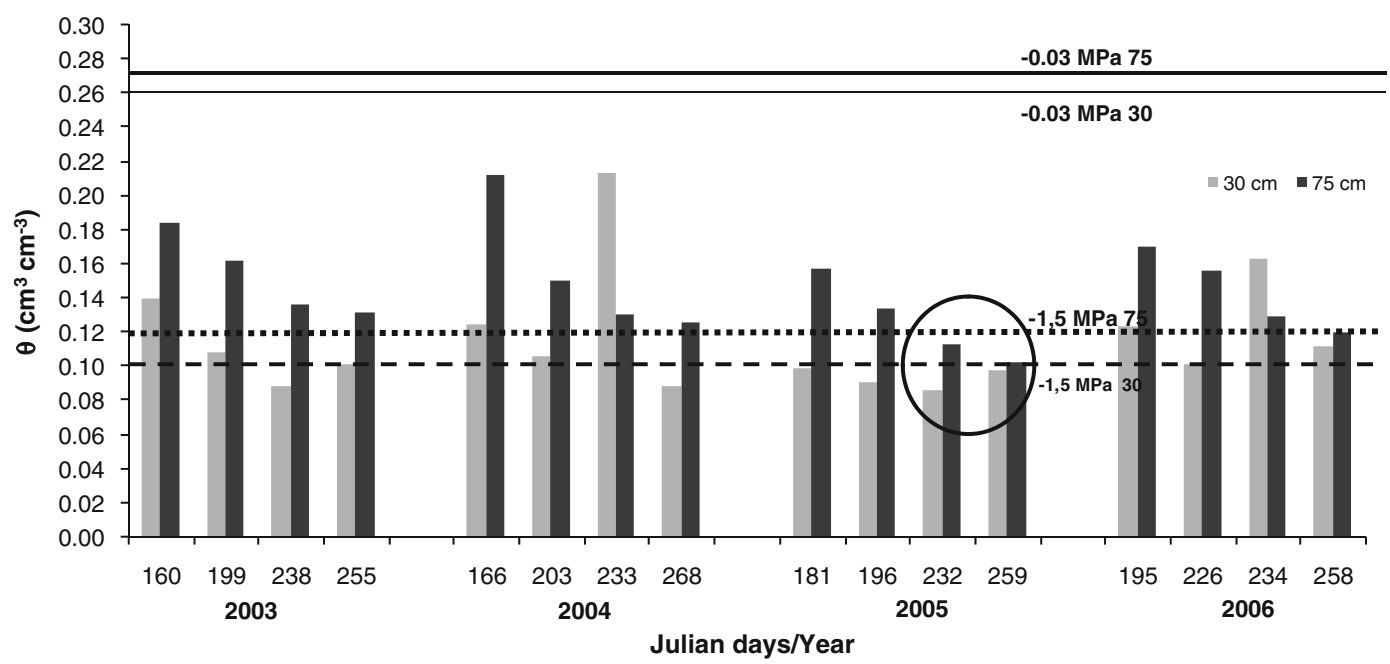

Fig. 3 Soil water content $(\theta)$ at $30 \mathrm{~cm}$ and $75 \mathrm{~cm}$ depth, measured in the summer period (Julian days) for the CT treatment, compared with soil water content measured at $-1.5 \mathrm{MPa}$ and-0.03 $\mathrm{MPa}$ on undisturbed samples from the same treatment. Circle indicates the very dry conditions in 2005

2005 showed small variation during the summer period and were consistently lower than that corresponding to the wilting point reference value.

The soil moisture content at the $75 \mathrm{~cm}$ depth was always below the field capacity and decreased during the drought period (Fig. 3). At the end of summer in 2003, 2004 and 2006, it was higher than that measured at-1.5 $\mathrm{MPa}$. In contrast, in 2005, from August 2005 onwards, which followed a wet season with much less rainfall than the average (see Table 2),
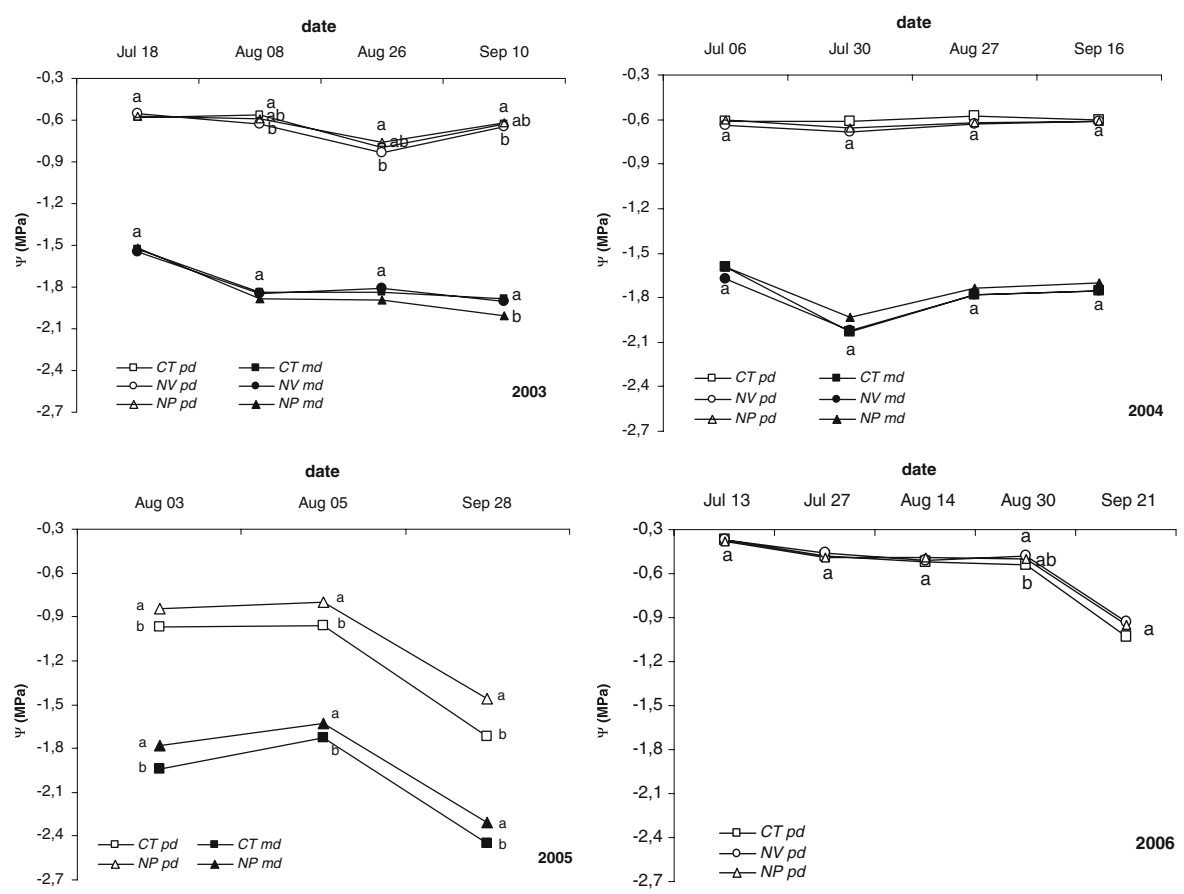

Fig. 4 Predawn (pd) and midday (md) leaf water potential measured in plots of CT, NP and NV treatments from June to September 2003-2006 $(n=12)$. Different letters at the same

date means significant differences $(\mathrm{p}<0.05)$ between treatments by the Tukey HSD multiple comparison test 

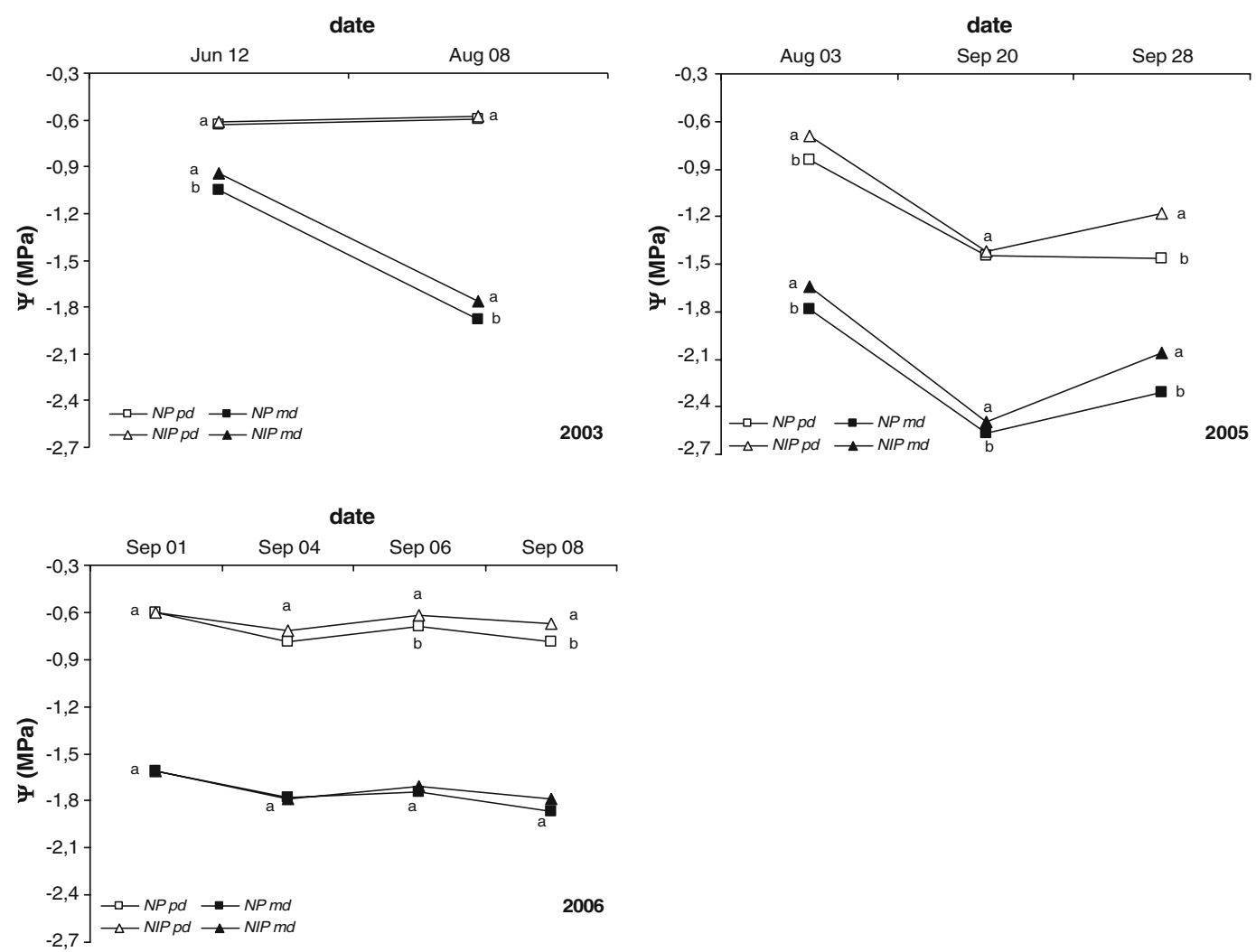

Fig. 5 Predawn (pd) and midday (md) leaf water potential $\left(\Psi_{\mathrm{W}}\right)$ measured in plots of the NP and NIP treatments in 2003, 2005 and 2006, from June to September $(n=12)$. Different

letters at the same date means significant differences $(\mathrm{p}<0.05)$ between treatments by the Tukey HSD multiple comparison test

the moisture contents were lower than the value measured at $-1.5 \mathrm{MPa}$.

Predawn leaf water potential $\left(\Psi_{\mathrm{wpd}}\right)$ and photosynthetic rate $(\mathrm{P})$

The value of predawn leaf water potential $\left(\Psi_{\text {wpd }}\right)$ was the parameter adopted in the present study to evaluate the .soil-plant-water relations which is illustrated in Figs 4 and 5. Treatments CT, NV and NP were used to compare the effect of conventional tillage versus maintenance of herbaceous vegetation cover (both natural and improved pasture), whereas NP and NIP treatments were considered, in order to observe the effect of irrigation in similar herbaceous vegetation cover.

Values of $\Psi_{\text {wpd }}$ in the CT, NV and NP treatments (Fig. 4), during the dry seasons of 2003, 2004 and 2006, were similar and in most of the study period were close to the value observed at the beginning of the summer period. Values of $\Psi_{\text {wpd }}$ ranged from -0.37 to $0.55 \mathrm{MPa}$, at beginning of July, and from -0.54 to $1.03 \mathrm{MPa}$, in late summer. In all treatments (in 2003

and 2004), midday leaf water potentials were of the same magnitude and ranged between -1.52 and $2.03 \mathrm{MPa}$.

In the driest year (2005), $\Psi_{\text {wpd }}$ values in the CT treatment were significantly lower than in the NP treatment, and were much lower than in the above mentioned years (Figs 4 and 5). Values at the beginning of August varied from -0.80 to $-0.96 \mathrm{MPa}$ in the NP and CT treatments, respectively, while at the end of September were much lower (-1.46 and 1.72 $\mathrm{MPa}$, respectively). A similar trend was observed for midday leaf water potential.

Relatively to the effect of irrigation, $\Psi_{\text {wpd }}$ values in treatments with similar vegetation (NP and NIP, respectively without and with irrigation) showed a similar trend along the dry season (Fig. 5). Values in the NIP were significantly higher than in the NP only in the dry seasons of 2005 and 2006. In both NP and NIP treatments, midday leaf water potential showed a pattern similar to that observed for predawn leaf water potential. 
Photosynthetic rate $(\mathrm{P})$ values, for the average of three standard days of the summer period, in 2003, 2005 and 2006, for the NP and NIP (just after the irrigations) treatments are illustrated in Fig. 6. In 2003, P values were higher for the NIP than for the NP treatment, with significant differences at 11:00 (respectively 8.88 and $6.22 \mu \mathrm{mol} \mathrm{CO} \mathrm{CO}_{2} \cdot \mathrm{m}^{-2} \cdot \mathrm{s}^{-1}$ ) and 13:00 (respectively 6.84 and $5.85 \mu \mathrm{mol} \mathrm{CO} 2 \cdot \mathrm{m}^{-2} \cdot \mathrm{s}^{-1}$ ). No significant differences were observed in 2005 and 2006; however, in 2005, the $\mathrm{P}$ values showed a strong decrease in relation to 2003 and 2006. The highest measured values of $P$ were 8.55-9.05 $\mu \mathrm{mol} \quad \mathrm{CO}_{2} \cdot \mathrm{m}^{-2} \cdot \mathrm{s}^{-1}$, when temperatures ranged from 21 to $25^{\circ} \mathrm{C}$ (2003 and 2006), decreasing to $5.58-6.84 \mu \mathrm{molCO} 2 \cdot \mathrm{m}^{-2} \cdot \mathrm{s}^{-1}$ for temperatures from 32.5 to $34.5^{\circ} \mathrm{C}$ (2003 and 2006).

Production of leaves, burs and nuts

A wide inter annual variability on production of leaves and burs and nuts was observed. Litterfall and fruit production showed significant differences among years and treatments (Table 3), and influence of years as a source of variation (42.3 and $52.2 \%$, respectively) was higher than that related to treatments (7.0 and $12.7 \%$, respectively). Also, a considerable error effect, attributed to the influence of trees and site quality was observed (50.7 and $32.8 \%$, respectively).

Dry matter production of leaves plus burs (Table 4) ranged from a minimum of about $317 \mathrm{~g} \mathrm{~m}^{-2}$ in 2005 to a

Fig. 6 Average values for daily $(9 \mathrm{~h}, 11 \mathrm{~h}$ and $13 \mathrm{~h})$ photosynthesis rate $(\mathrm{P})$ in NIP and NP treatments and air temperature $(\mathrm{T})$ for three standard days of summer period $(\mathrm{n}=36)$ in 2003 (12 June, 8 August, 12 September), 2005 (3 and 5 August, 20 September) and 2006 (16 August, 1 and 8 September). Bars show SE maximum of $613 \mathrm{~g} \mathrm{~m}^{-2}$ in 2003. Values for the CT $\left(440 \mathrm{~g} \mathrm{~m}^{-2}\right)$ and NP (486 $\left.\mathrm{g} \mathrm{m}^{-2}\right)$ treatments were significantly lower than in the NV $\left(607 \mathrm{~g} \mathrm{~m}^{-2}\right)$ treatment. The lowest fruit production $\left(9.2 \mathrm{~kg}\right.$ tree $\left.^{-1}\right)$ was also observed in 2005, and was significantly different from that in the other study years (25.5 $27.9 \mathrm{~kg}$ tree $\left.^{-1}\right)$. Production in the CT and NP (18.8 and $19.6 \mathrm{~kg} \mathrm{tree^{-1 }}$, respectively) was significantly lower than in the NIP and NV treatments $(24.4 \mathrm{~kg}$ and $27.2 \mathrm{~kg}$ tree $^{-1}$, respectively). As illustrated in Fig. 7, nut production between treatments in the driest year varied from 4 to $12 \mathrm{~kg}^{-1}$ tree ${ }^{-1}$ while ranged from 20 to $35 \mathrm{~kg}$ tree $^{-1}$ in 2004.

\section{Discussion}

The application of the no tillage system (with maintenance of spontaneous herbaceous vegetation cover) did not lead to negative effects on water content in the soil. This pattern is in agreement with observations in similar systems reported by Raimundo (2003) and Martins et al. (2005) in which no advantages of conventional tillage on water saving were observed, as compared with the maintenance of natural vegetation cover. This trend also agrees with results from studies developed on cereal crops (Bescansa et al. 2006) and olive orchards (Hernandéz et al. 2005), under semi arid climatic conditions,

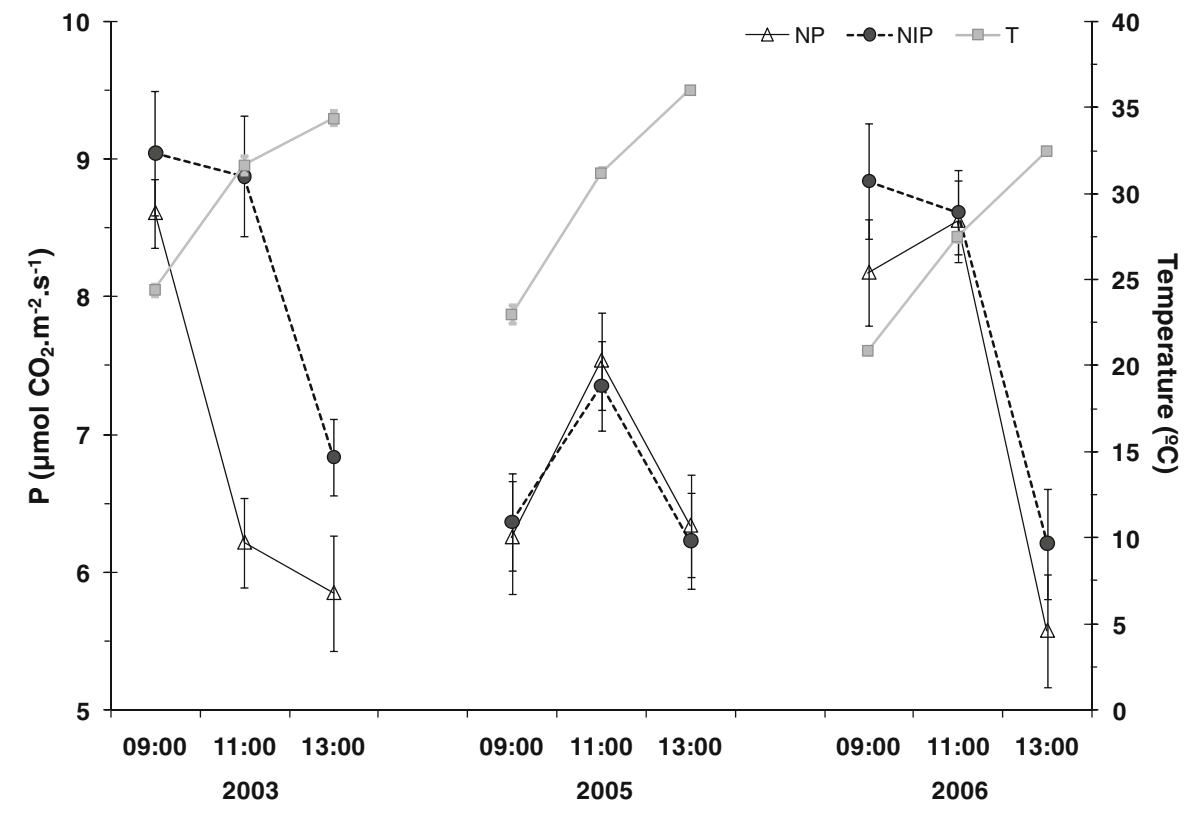


Table 3 Analysis of variance related to the effect of years and treatments on litterfall and fruit production. No significant interactions are not shown

\begin{tabular}{lrrrrr}
\hline Source of variation & df & Mean square & F-value & P-value & Expected variation (\%) \\
\hline Litterfall & & & & & \\
Year (Y) & 3 & $2,910.22$ & 30.58 & 0.0001 & 42.3 \\
Treatments (T) & 3 & 564.76 & 5.93 & 0.0008 & 7.0 \\
Error (trees/T/Y) & 126 & 95.18 & & & 50.7 \\
Nut production & & & & & \\
Year (Y) & 3 & $632,177.58$ & 55.09 & 0.0001 & 52.2 \\
Treatments (T) & 3 & $162,967.26$ & 14.20 & 0.0001 & 12.7 \\
Error (trees/T/Y) & 120 & $11,475.71$ & & & 32.8 \\
\hline
\end{tabular}

where a positive effect of no tillage on soil water content and storage was observed when compared with tillage practices. Also, the installation of a pasture showed no effect on soil moisture when compared with the conventional tillage system (CT treatment). We may emphasize that in the no tillage system the vegetation cover may partially be controlled by the build up of organic layers on the soil surface, as reported by Raimundo et al (2008). Similar soil water contents in the NV and CT treatments may be also explained by small variations in soil organic matter contents, which were reported by Raimundo et al. (2008) in a previous study (8-year period) in the same region.

Our results indicate that water availability in the soil profile is mostly dependent on weather conditions regarding rainfall distribution. Although in the four year study period soil moisture contents, at the $30 \mathrm{~cm}$ soil depth, lower than that measured at $-1.5 \mathrm{MPa}$ were observed, values measured in the dry season of the driest year (2005) were consistently lower than this reference value. However, soil moisture contents much higher than that corresponding to the wilting point were obtained in certain summer periods (see Fig. 3), which were related to rainfall events during summer. As the drought period progressed, an increasing proportion of water was extracted from deeper soil layers, confirming previous studies (Garnier et al 1986). However, soil moisture content at the $75 \mathrm{~cm}$ depth during drought seasons only reach the value measured at $-1.5 \mathrm{MPa}$ (the threshold corresponding to the wilting point: Brady and Weil 1999; Hillel 2004) in the driest year of the study period. This pattern is in agreement with the wide differences between rainfall and reference evapotranspiration observed during the October-May periods (5-710 $\mathrm{mm}$; see Table 2), indicating that strong decreases in rainfall during such periods may nega- tively affect the replenishment of water retention capacity of deep soil layers.

In the present study, $\Psi_{\text {wpd }}$ values showed a small variation during the drought season, following the pattern reported by Cubera and Moreno (2007) and Moreno et al. (2007) for Quercus ilex trees growing in a drier site (precipitation: 500-600 $\mathrm{mm}$ ), with deeper soils and lower tree density (9-35 trees/ha). However, our results are not in total agreement with those reported by David et al. (2007) for both Q. ilex and $Q$. suber stands (about 30 trees/ha) under Mediterranean conditions in southern Portugal $\left(665 \mathrm{~mm}, 15 \mathrm{C}^{\circ}\right)$, in which much lower values $(-1.7$ to $-2.3 \mathrm{MPa})$ were observed in summer. Only in the driest year (2005) $\Psi_{\text {wpd }}$ values (-0.7 to $-1.7 \mathrm{MPa}$ ) were close to those measured by David et al. (2007), which agrees with

Table 4 Litterfall (g DM m${ }^{-2}$ of leaves + burs) and fruit $(\mathrm{kg}$ DM tree ${ }^{-1}$ ) production according to years and treatments during the study period

\begin{tabular}{llllll}
\hline Year & $\mathbf{n}$ & Mean \pm SE & Treatment & n & Mean \pm SE \\
\hline \multicolumn{7}{l}{ Litterfall } \\
2003 & 36 & $612.6 \pm 20.7 \mathrm{c}$ & $\mathrm{CT}$ & 32 & $440.0 \pm 28.5 \mathrm{a}$ \\
2004 & 36 & $573.3 \pm 20.7 \mathrm{bc}$ & $\mathrm{NP}$ & 34 & $485.6 \pm 27.7 \mathrm{ab}$ \\
2005 & 36 & $316.7 \pm 20.7 \mathrm{a}$ & NPI & 36 & $501.0 \pm 26.9 \mathrm{~b}$ \\
2006 & 28 & $541.7 \pm 23.4 \mathrm{~b}$ & NV & 34 & $606.5 \pm 27.7 \mathrm{c}$ \\
Nut production & & & & \\
2003 & 39 & $27.9 \pm 1.6 \mathrm{~b}$ & $\mathrm{CT}$ & 34 & $18.8 \pm 2.1 \mathrm{a}$ \\
2004 & 36 & $25.5 \pm 1.7 \mathrm{~b}$ & NP & 37 & $19.6 \pm 2.0 \mathrm{a}$ \\
2005 & 36 & $9.2 \pm 1.7 \mathrm{a}$ & NPI & 36 & $24.4 \pm 2.1 \mathrm{~b}$ \\
2006 & 31 & $27.8 \pm 1.8 \mathrm{~b}$ & NV & 35 & $27.2 \pm 2.1 \mathrm{~b}$ \\
\hline
\end{tabular}

Different letters in the same column means significant differences $(p<0.05)$ between years or treatments by the Tukey HSD multiple comparison test 


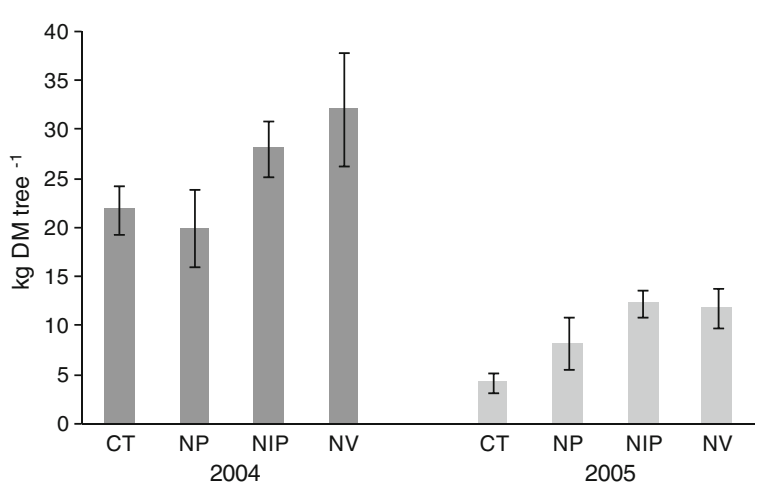

Fig. 7 Nut production ( $\mathrm{kg} \mathrm{DM}$ per tree) in the different treatments for 2004 and $2005(n=9)$. Bars show SE

the low soil moisture content observed in both surface and deep soil layers. Our $\Psi_{\text {wpd }}$ results indicate that trees were consuming a high volume of water for transpiration during the drought period. Given the high tree density in chestnut plantations (about 70 trees/ha), higher $\Psi_{\text {wpd }}$ values than in the above mentioned $Q$. ilex stands are found to be unexpected. In addition, the amount of available water in the soil up to the $75 \mathrm{~cm}$ depth at the beginning of the summer was negligible; for instance, in 2003 and 2004 it was less than $5 \mathrm{~mm}$. Therefore, the high $\Psi_{\text {wpd }}$ values observed in the present study during the drought season may be mostly explained by the water uptake from deeper layers of the soil and soil parent material. It means that chestnut trees, as reported for evergreen oak trees (e. g. Q. suber and $Q$. ilex) in climates with seasonal drought (Bréda et al. 1995; Breman and Kessler 1995; Canadell et al. 1996; Otieno et al. 2006; David et al. 2007), rely on deep roots and the ability to uptake water from sources in the subsoil including permanent water tables. It is also evident that chestnut trees may have a deep root system facilitated by the fractured nature of the rock (schists), as reported by David et al. (2007) for Q. ilex trees, in southern Portugal. However, further studies on chestnut root system and the evidence of water tables are needed for a better understanding of the water use pattern by chestnut plantations.

Values of $\Psi_{\text {wpd }}$ in the conventional tillage system were similar to those in rainfed treatments with vegetation cover ( $\mathrm{NV}$ and $\mathrm{NP}$ ), indicating that herbaceous plant cover (either natural or rainfed improved pastures) may have no negative effects on soil and plant water status or tree water relationships. This trend is supported by findings of Gakis et al. (2004), in a study of understory effects on early stage trees growing with Acer pseudoplatanus and Pinus sylvestris. These authors reported that understory species cover, in Mediterranean conditions, can compete with trees in the early stage after plantation, but as the root system of trees goes deeper, mature trees are less dependent on water competition by herbaceous vegetation of surface soil layers. In the present study, treatments were installed in chestnut mature stands where tree root systems were mostly located below $20 \mathrm{~cm}$ soil depth due to root damage through harrowing operations, as reported by Raimundo (2003). Therefore, a certain degree of spatial separation between herbaceous plants and trees may occur, following the trend observed by Cubera and Moreno (2007) for holm oak stands in Spain, where herbaceous roots are mostly in the upper $30 \mathrm{~cm}$ of soil (Moreno et al. 2005). As chestnut trees have a high reliance on deep water, it seems that trees and herbaceous vegetation are, for the most part, consuming water from different soil layers, thus preventing below ground competition. Moreover, rainfed improved pastures, as reported for vineyards (Morlat and Jacquet 2003; Celette et al. 2008) and dryland agroforestry (Lehmann et al. 1998), may also force the tree root system to explore deeper soil layers, thus partly preventing direct competition for water resources.

Tree water status in irrigated plots (NIP treatment) followed the same pattern and showed small differences regarding the rainfed treatment with similar vegetation (NP). This suggests a negligible effect of the irrigation system on soil and tree water status (Fig. 7) and that the irrigation water supplied was not sufficient to alleviate the deficit of available water in deep soil layers. However, this trend disagrees with that reported by Gomes-Laranjo et al. (2006) for young almond trees, under similar irrigation system, where a positive response of $\Psi_{\text {wpd }}$ and $\mathrm{P}$ values to irrigation was observed. Such a difference may be attributed to the fact that almond trees were young and growing in the absence of herbaceous vegetation, and therefore with a root system still dependent on the upper soil layers. We may underline that, independently of leaf water potential and soil water availability, the photosynthetic rate sharply decreased when air temperature increased to $33^{\circ} \mathrm{C}$. These data are consistent with previous studies (Gomes-Laranjo et al. 2005), in which the $\mathrm{P}$ of C. sativa was shown to be dependent on air temperature, but independent of soil management. 
Despite similar $\Psi_{\text {wpd }}$ values in the CT and NV treatments, nut production was significantly lower in the former than in the latter, corroborating results reported by Raimundo (2003) in the same region. The advantage of the no tillage system with spontaneous herbaceous vegetation may be associated with the fact that the damage of the tree root system is avoided and organic C losses reduced. Also, the build up of soil organic layers, as reported by Raimundo et al. (2008), creating a mulching effect, may increase soil organic matter content and reduce soil erosion risks (Bescansa et al. 2006). This and the occurrence of a herbaceous vegetation cover may also improve soil surface structure, change pore-size distribution, increase permeability as compared with the conventional system, and favour water soil replenishment during the winter, as reported for vineyards in southern France (Celette et al. 2005). However, the nut production in the no tillage system with seeded pasture was significantly lower than that observed in the no tillage system with spontaneous herbaceous vegetation. This may be related to greater amounts of herbaceous vegetation in the former than in the latter (2.4 and $0.8 \mathrm{t} \mathrm{DM} \mathrm{ha}^{-1}$, respectively, as reported by Raimundo, 2003, in a previous study), and to the fact that seeded pasture (with leguminous species) may be more competitive for water resources than spontaneous species as concluded in a study with walnut trees (Dupraz et al. 1998). However, long term studies are needed to evaluate how competition patterns are balanced by the improved soil organic matter and nitrogen status in the seeded pasture system.

Inter annual variation in nut productivity was much stronger than that related to management systems, in relation to the wide variability of weather conditions regarding rainfall (see Tables 2 and 4). This is in line with findings of Raimundo et al. (2008) who showed that chestnut productivity is positive and strongly related to the rainfall during the October-May period. In addition, differences between treatments regarding productivity were stronger in the driest year (2005), when significant differences in $\Psi_{\text {wpd }}$ values between the conventional and the no tillage systems were observed (see Figs. 4 and 7). For instance, nut production in this year under the conventional tillage system was only $35-62 \%$ of that measured in the other treatments (see Fig. 7), while in 2004 it attained 68$110 \%$. This suggests that the traditional tillage is more deleterious to the system under prevailing conditions of severe drought. Thus, taking into account nut production and the projection in increases in length, severity and frequency of summer droughts (Miranda et al. 2002), conventional tillage should be replaced by conservative practices (e.g. no tillage with spontaneous vegetation cover) to maintain the long-term sustainability of the chestnuts stands in Northern Portugal.

Although irrigation treatment (NIP) led to higher nut production than in the $\mathrm{CT}$ and NP treatments, it did not show any advantage when compared with the NV treatment (Table 4), which is in agreement with the similar predawn leaf water potentials observed in both treatments (Figs 4 and 5). This suggests that the irrigation schedule followed in the NIP treatment, that is, the supply of water affecting only the top soil layer, did not lead to an enhancement of soil water availability during summer drought and was ineffective on nut production. In chestnut stands, as in deepwater-dependent ecosystems (Cooper et al. 2003), plant water stress, leaf shading and even tree mortality may increase when deep water resources decline, as observed in 2005. Therefore, as for Mediterranean evergreen ecosystems, the main threat for chestnut systems comes from the enhanced severity of summer drought caused by climate change. For instance, the severe drought of 2005 led to a strong decline in tree gas exchange as observed for southern regions of Portugal (David et al., 2007). In this context, the scarcity of water resources may lead to increased groundwater extraction for human use, which further aggravates the climatic effects on groundwater resources, with strong negative impacts on the sustainability of chestnut ecosystems, since these trees seem to be strongly dependent on subsoil water sources. Therefore, the use of irrigation system is questioned and the development of other strategies of irrigation application in order to enhance its efficiency is needed.

\section{Conclusions}

Weather conditions, especially rainfall, showed a wide variation during the study period with implications on the water storage in the soil profile and on the physiological responses of chestnut trees. Soil water storage in deep layers played an important role in water uptake by trees, which requires the capability of deep root development to assure the resistance to 
drought. Although the global scenario of increasing temperature may affect chestnut productivity, it is mostly related to the occurrence of erratic and extremely dry years. The use of irrigation with seeded pasture does not have clear advantage on soil water regime, tree physiological response and nut production, which indicate the need to develop new irrigation strategies to increase water use efficiency. No tillage and maintenance of spontaneous herbaceous vegetation, with lower requirements for water over improved seed pasture, seems to be at the moment the most favourable management system to assure productive sustainability of chestnut stands.

Acknowledgements The authors thank to the European project MANCHEST (Contract QLK5-2001-00029), PROCAST project (No 391 of AGRO program), which supported this study. José Lousada is acknowledged for assistance in statistical analysis. A special thanks to Professor Salvatore Leonardi coordinator of the first project, who passed away on 2004 summer, for his enthusiasm and contribution to chestnut ecology research.

\section{References}

Abreu CG, Coutinho JF, Cardoso AO, Campos JA (1993) Suppressive soils and chestnut ink disease. In Proc. International Congress on Chestnut, E. Antognozzi (ed.), Spoleto, Italy, 533-536

Bescansa P, Imaz MJ, Virto I, Enrique A, Hoogmoed WB (2006) Soil water retention as affected by tillage and residue management in semiarid Spain. Soil Tillage Res 87:19-27. doi:10.1016/j.still.2005.02.028

Brady NC, Weil RR (1999) The Nature and Properties of Soils. Prentice Hall, Upper Saddle River, New Jersey. ISBN 12

Bréda N, Granier A, Barataud F, Moyne C (1995) Soil water dynamics in an oak stand 1 . Soil moisture, water potentials and water uptake by roots. Plant Soil 172:17-27. doi:10.1007/BF00020856

Breman H, Kessler JJ (1995) Woody Plants in Agro-ecosystems of Semi-Arid Regions. Advanced Series in Agricultural Sciences 23, Springer-Verlag, Berlin

Canadell J, Jackson RB, Ehleringer JR, Mooney HA, Sala OE, Schulze ED (1996) Maximum root depth of vegetation types at the global scale. Oecologia 108:583-595. doi:10.1007/BF00329030

Celette F, Gaudin R, Gary C (2008) Spatial and temporal changes to the water regime of a Mediterranean vineyard due to the adoption of cover cropping. Eur J Agron 29:153-162. doi:10.1016/j.eja.2008.04.007

Celette F, Wery J, Chantelot E, Celette J, Gary C (2005) Belowground interactions in a vine (Vitis vinifera $\mathrm{L}$ )-tall fescue (Festuca arundinacea Shreb.) intercropping system: water relations and growth. Plant Soil 276:205-217. doi:10.1007/s11104-005-4415-5
Cooper DJ, D’Amico DR, Scott ML (2003) Physiological and morphological response patterns of Populus deltoides to alluvial groundwater pumping. Environ Manage 31:215226. doi:10.1007/s00267-002-2808-2

Cubera E, Moreno G (2007) Effect of single Quercus ilex trees upon spatial and seasonal changes in soil water content in dehesas of central western Spain. Ann Sci 64:355-364. doi:10.1051/forest:2007012

David TS, Henriques MO, Kurz-Besson C, Nunes J, Valente F, Vaz M, Pereira JS, Siegwolf R, Chaves MM, Gazarini LC, David JS (2007) Water-use strategies in two co-occurring Mediterranean evergreen oaks: surviving the summer drought. Tree Physiol 27:793-803

Dupraz C, Simorte V, Dauzat M, Bertoni G, Bernadac A, Masson P (1998) Growth and nitrogen status of young walnuts as affected by intercropped legumes in a Mediterranean climate. Agrofor Syst 43:71-80. doi:10.1023/ A:1026499103899

FAO (1979) Yield response to water FAO irrigation and drainage, paper 33. FAO, Rome

FAO-IUSS-ISRIC (2006) World reference base for soil resources, 2nd edn. World Soil Resources Reports No. 103. FAO, Rome

FAO 2004 FAOSTAT, Database Collections, Agricultural Data. http://faostat.fao.org

Fereres E, Evans RG (2006) Irrigation of fruit trees and vines: an introduction. Irrig Sci 24:55-57. doi:10.1007/s00271005-0019-3

Gakis S, Mantzanas K, Alifragis D, Papanastasis VP, Papaioannou A, Seilopoulos D, Platis P (2004) Effects of understorey vegetation on tree establishment and growth in a silvopastoral system in northern Greece. Agrofor Syst 60:149-157. doi:10.1023/B:AGFO.0000013275.30617.ad

Garnier F, Berger A, Rambal S (1986) Water balance and pattern of soil water uptake in a peach orchard. Agric Water Manage 11:145-158. doi:10.1016/0378-3774(86)90027-2

Glenn DM, Welker WV (1989) Cultural practices for enhanced growth of young peach trees. Am J Altern Agric 4:8-11

Gomes-Laranjo JCE, Peixoto F, Wong Fong Sang HW, TorresPereira JMG (2005) Study of the temperature effect in three chestnut (Castanea sativa Mill.) cultivars'behaviour. J Plant Physiol 163:945-955. doi:10.1016/j.jplph.2005.06.020

Gomes-Laranjo JCE, Coutinho JP, Gallhano V, Cordeiro V, TorresPereira J (2006) Responses of five almond cultivars to irrigation: Photosynthesis and leaf water potential. Agric Water Manage 83:261-265. doi:10.1016/j.agwat.2005.11.007

Hargreaves GH (1975) Moisture availability and crop production. Trans Am Soc Agric Eng 18(5):980-984

Hernandéz AJ, Lacasta C, Pastor J (2005) Effects of different management practices on soil conservation and soil water in a rainfed olive orchard. Agric Water Manage 77:232248. doi:10.1016/j.agwat.2004.09.030

Hillel D (2004) Introduction to Environmental Soil Physics. Elsevier, Amsterdam

Hogue EJ, Neilsen GH (1987) Orchard floor vegetation management. Hortic Rev (Am Soc Hortic Sci) 9:377-430

INE (2005) Estatísticas Agrícolas 2004 Instituto Nacional de Estatística. Lisboa, Portugal

INMG (1991) Normais Climatológicas da Região de Trás-osMontes e Alto Douro e Beira Interior, Correspondentes a 1951-1980 O Clima de Portugal. Fascículo XIII, Vol. 3- $3^{\text {a }}$ 
Região. Instituto Nacional de Meteorologia e Geografia, Lisboa

Kramer PJ (1969) Plant and Soil Water Relationships: a Modern Synthesis. McGraw-Hill Book Company, New York

Lehmann J, Peter I, Steglich C, Gebauer G, Huwe B, Zech W (1998) Below-ground interactions in dryland agroforestry. For Ecol Manage 111:157-169

Lipecki J, Berbeć S (1997) Soil management in perennial crops: stands and hop gardens. Soil Tillage Res 43:169-184. doi:10.1016/S0167-1987(97)00039-1

Lyon DJ, Stroup WW, Brown RE (1998) Crop production and soil water storage in long-term winter wheat-fallow tillage experiments. Soil Tillage Res 49:19-27. doi:10.1016/ S0167-1987(98)00151-2

Marcelino V, Torres N, Portela E, Martins A (2000) Soil physical properties and the occurrence of chestnut ink disease: a micromorphological study. Ecol Mediterranea 26:129-135

Marshall TJ, Holmes JW (1988) Soil Physics (2 ${ }^{\text {nd }}$ ed.). Cambridge University Press

Martins LM, Abreu CG (1997) Solos supressivos: um meio de luta cultural contra a doença da tinta do castanheiro. Rev Biol 16:113-117

Martins A, Linhares I, Raimundo F, Borges O, Coutinho JP, Gomes-Laranjo J, Sousa V (2005) The importance of deep soil layers to supply water to agroforestry system: A case study of a mature chestnut orchard in Northern Portugal. Proc. 3td Int. Chestnut Congress. Eds. C G Abreu, E Rosa and A A Monteiro. Acta Hortic 693:663-670

Martins LM, Oliveira MT, Abreu CG (1999) Soils and climatic characteristics of chestnut stands that differ on the presence of ink disease. Acta Hortic 494:447-449

Miranda P, Coelho FES, Tomé AR, Valente MA (2002) 20th century Portuguese climate and climate scenarios. In: Santos FD, Forbes K, Moita R (eds) Climate Change in Portugal: Scenarios, Impacts and Adaptation Measures. SIAM project, Gradiva, Lisboa, pp 25-83

Moreno G, Obrador JJ, Cubera E, Dupraz C (2005) Fine root distribution in Dehesas of Central-Western Spain. Plant Soil 277:153-162. doi:10.1007/s11104-005-6805-0

Moreno G, Obrador JJ, García E, Cubera E, Montero MJ, Pulido F, Dupraz C (2007) Driving competitive and facilitative interactions in oak dehesas through management practices. Agrofor Syst 70:25-40. doi:10.1007/s10457-007-9036-y

Morlat R, Jacquet A (2003) Grapevine root system and soil characteristics in a vineyard maintained long-term with or without interrow sward. Am J Enol Vitic 54:1-7

Morris RA, Garrity DP (1993) Resource capture and utilization in intercropping: water. Field Crops Res 34:303-317. doi:10.1016/0378-4290(93)90119-8

Otieno DO, Kurz-Bresson C, Liu J, Schmidt MWT, Vale-Lobo R, David TS, Siegwolf R, Pereira JS, Tenhunen JD (2006) Seasonal variations in soil and plant water status in a Quercus suber L. stand: roots as determinants of tree productivity and survival in the Mediterranean-type climate. Plant Soil 283:119-135. doi:10.1007/s11104-004-7539-0

Pereira LS, Cordery I, Iacovides I (2002a) Croping with Water Scarcity. UNESCO IHP VI, Technical Documents in Hydrology No. 58. UNESCO, Paris, p 267

Pereira LS, Oweis T, Zairi A (2002b) Irrigation management under water scarcity. Agric Water Manage 57:175-206. doi:10.1016/S0378-3774(02)00075-6

Portela E, Aranha J, Martins A, Pires AL (1999) Soil factors, farmer's practices and chestnut ink disease: some interactions. Acta Hortic 494:433-441

Raimundo F (2003) Sistemas de mobilização do solo em soutos: Influência na produtividade de castanha e nas características físicas e químicas do solo. $\mathrm{PhD}$ thesis. Universidade de Trás-os-Montes e Alto Douro, Vila Real, Portugal

Raimundo F, Martins A, Madeira M (2008) Decomposition of chestnut litterfall and eight-year soil chemical changes under a no-tillage management system in Northern Portugal. Ann Sci 65(4). doi:10.1051/forest:2008021

Stigter TY, Ribeiro AMM, Carvalho D (2006) Evaluation of an intrinsic and a specific vulnerability assessment method in comparison with groundwater salinisation and nitrate contamination levels in two agricultural regions in the south of Portugal. Hydrogeol J 14:79-99. doi:10.1007/ s10040-004-0396-3

SNIRH - Sistema Nacional de Informação de Recursos Hídricos 2005. http://snirh.inag.pt

White RE (2006) Principles and Practice of Soil Science. The Soils as a Natural Resource (fourth ed.). Blackwell Publishing. 